\title{
Chronic Granulomatous Disease: Uptake and Intracellular Activity of Fosfomycin in Granulocytes
}

\author{
P. H. HÖGER, R. A. SEGER, U. B. SCHAAD, AND W. H. HITZIG \\ Department of Pediatrics [P.H.H., R.A.S., W.H.H.], Division of Immunology-Hematology, University of Zürich, \\ Zürich, and the Department of Pediatrics [U.B.S.], Division of Infectious Diseases, University of Bern, Bern, \\ Switzerland
}

\begin{abstract}
In chronic granulomatous disease (CGD) polymorphonuclear leukocytes (PMN) are unable to kill phagocytized catalase-positive bacteria. Therefore, patients with CGD are prone to infections and dependent on antimicrobial agents able to penetrate PMN membranes and to act intracellularly. Owing to their good lipid solubility, trimethoprim/sulfamethoxazole and rifampicin passively diffuse the membrane. In contrast, fosfomycin is transported actively into the cell. In normal PMN, it reaches cellular-to-extracellular ratios of 1.83 after $15 \mathrm{~min}$, in CGD-PMN 2.18 after $30 \mathrm{~min}$. At concentrations between 16 and $200 \mathrm{mg} / \mathrm{liter}$, fosfomycin was able to kill staphylococci surviving within CGD-PMN, thus compensating for the bactericidal deficiency in CGD. A combination of low concentrations of fosfomycin $(8 \mathrm{mg} / \mathrm{liter})$ plus rifampicin $(0.06 \mathrm{mg} / \mathrm{liter})$ was more effective at the intracellular level than either agent alone. Apart from a stimulation of PMN-chemiluminescence of yet unknown significance, the agent did not interfere with other neutrophil functions. Clinical investigations are indicated to study whether fosfomycin can be added to the small number of antibiotics useful in CGD. (Pediatr Res 19: 38-44, 1985)
\end{abstract}

$\quad$ Abbreviations
C/E, cellular-to-extracellular concentration ratio
C/Emax, maximal C/E
CFU, colony forming unit
CGD, chronic granulomatous disease of childhood
DOG, deoxyglucose
DPM, disintegrations per minute
HBSS, Hanks' balanced salt solution
HBSS + serum, HBSS supplemented with $15 \%$ pooled
normal human serum
KCN, potassium cyanide
OPZ, opsonized zymosan
PMA, phorbol myristate acetate
PMN, polymorphonuclear leukocytes
RT, room temperature (20 C)
TMP/SMZ, trimethoprim/sulfamethoxazole
ZAS, zymosan-activated serum

Received March 29, 1984; accepted July 23, 1984.

Correspondence W. H. Hitzig, M.D., Dept. of Pediatrics, Div. ImmunologyHematology, University of Zürich, Steinwiesstrasse 75, CH-8032 Zürich, Switzerland.

Supported by the Swiss National Foundation (grant 3.884-0.81), Jubiläumsstiftung der Schweizerischen Lebensversicherungs und Rentenanstalt, Schweizerische Krebsliga, and Theodor-and-Ida-Herzog-Egli-Stiftung.
Common to the nine different types of CGD described to date (20) is a defect of the NADPH-oxidase system located in the PMN membrane. Production of hydrogen peroxide $\left(\mathrm{H}_{2} \mathrm{O}_{2}\right)$ during phagocytosis is lacking. Consequently, the patients are prone to infections by catalase-positive bacteria (e.g. staphylococci, Escherichia coli, klebsiella, serratia) and fungi (mainly Aspergillus spp.). Initially, recurrent, purulent infections are located on skin and mucous membranes. Later, phagocytized, but still viable bacteria may spread within the PMN throughout the body, causing osteomyelitis and liver and lung abscesses (20).

For prevention and treatment of infections in CGD, antibiotics capable of penetrating PMN membranes, accumulating intracellularly, and revealing bactericidal activity within the phagocytic vacuoles are required. Host defense should not be adversely affected by such drugs $(27,29)$. These stringent requirements are met by only a small number of antimicrobial agents. TMP/SMZ is now generally accepted as the drug of choice for continuous antibacterial prophylaxis in these patients $(20,26)$. Rifampicin is mainly administered in cases of intercurrent staphylococcal infections $(4,21)$. The need for additional antibiotics applicable in CGD is evident, especially in cases of severe infections by bacteria resistant to TMP/SMZ or in cases of allergic reactions toward this agent.

Fosfomycin was identified in the culture filtrates of several streptomyces species (28). It has a low molecular weight of 138.06 daltons and is structurally unrelated to any other known antibiotic substance, exhibiting an unusual direct linkage between carbon and phosphate. Bactericidal activity is exerted through inhibition of the enzyme important for the first step in bacterial cell wall synthesis (N-acetylglucosamino-3-o-enol-pyruvyl-transferase) (12). Fosfomycin is taken up into bacteria by two active transport systems (12). Its antibacterial activity in vitro $(5,9)$ includes organisms important in CGD (20). Rate and severity of side-effects are reported to be low $(8,9,13,28)$.

Because of these favorable characteristics, we investigated whether fosfomycin fulfills the in vitro requirements for an antibiotic useful in therapy of chronic intracellular infections. Due to their unique metabolic anomaly, CGD-PMNs represent an excellent model for the study of the intracellular bactericidal activity of antibiotics.

\section{MATERIALS AND METHODS}

Isolation of PMN. Heparinized blood, $40-120 \mathrm{ml}$, was taken from 20 healthy volunteers (male and female, aged 20-45 yr) and 10 CGD-patients (male, aged 3-22 yr) with informed consent. Antibiotics were discontinued at least $24 \mathrm{~h}$ before sampling. Neutrophil granulocytes were isolated after dextran sedimentation and Ficoll-Hypaque gradient centrifugation as previously 
described (3). Viability of the cells was determined using the Trypan blue dye exclusion test.

Intracellular uptake of antibiotics. Uptake of antibiotics into PMN from healthy blood donors and CGD patients was measured as described before $(11,14,21)$, but with several minor modifications. $2.2 \mathrm{ml}$ of a PMN-suspension $\left(3 \times 10^{7} \mathrm{PMN} / \mathrm{ml}\right.$ HBSS) were preincubated in a water bath at $37^{\circ} \mathrm{C}$ for $10 \mathrm{~min}$. The following radiolabeled antibiotics were tested: either ${ }^{3} \mathrm{H}$ fosfomycin (disodium-L-cis-I,2-epoxy-[ $\left.{ }^{3} \mathrm{H}\right]$ propylphosphonate, specific activity: $59.9 \mu \mathrm{Ci} / \mathrm{mg}$, supplied by Boehringer, Mannheim, FRG) or $\left[{ }^{14} \mathrm{C}\right]$ rifampicin (I-methyl-4-amino- $\left(3,5-\left[{ }^{14} \mathrm{C}\right] \mathrm{pi}-\right.$ perazin-rifamycin, $4 \mu \mathrm{Ci} / \mathrm{mg}$, Ciba Geigy, Basle, Switzerland), $\left[{ }^{14} \mathrm{C}\right]$ trimethoprim (2,4-diamino-5-(3,4,5-trimethoxybenzal)-2$\left[{ }^{14} \mathrm{C}\right]$ pyrimidine, $40 \mu \mathrm{Ci} / \mathrm{mg}$, Wellcome Research Lab., Basle, Switzerland), $\left[{ }^{35}\right.$ S $]$ sulfamethoxazole $\cdot\left(3-\left[{ }^{35}\right.\right.$ S $]$ sulfanilamido-5methylisoxazole, $26.54 \mu \mathrm{Ci} / \mathrm{mg}$, Amersham Int., Amersham, $\mathrm{UK}$ ), or $\left[{ }^{14} \mathrm{C}\right]$ penicillin (benzyl- $\left[{ }^{14} \mathrm{C}\right]$ penicillin-potassium, 140 $\mu \mathrm{Ci} / \mathrm{mg}$, Amersham).

The antibiotics were added at the following final concentrations: fosfomycin 1, rifampicin 2, trimethoprim 10, sulfamethoxazole 4.5 , penicillin $35 \mu \mathrm{g} / \mathrm{ml}$ HBSS. The PMN/buffer coefficients were determined $30,(75), 90 \mathrm{~s}$ and $3,5,10,(15), 20$, and $30 \mathrm{~min}$ after the addition of antibiotics. Three-hundred- $\mu$ l aliquots $\left(1 \times 10^{7} \mathrm{PMN}\right)$ were centrifuged across a gradient of silicone oil into a layer of sucrose at the bottom of the centrifugation tube. The cells containing the intracellular antibiotic activity formed a pellet. The extracellular antibiotic activity, which did not permeate the water-impermeable silicone, was found in the supernatant above the silicone layer. After treatment with $1 \mathrm{ml}$ of tissue solubilizer (Soluene 100, Packard, Downers Grove, IL) and subsequent addition of $10 \mathrm{ml}$ scintillation fluid (Econofluor, NEN, Dreieich, FRG), 200- $\mu$ l aliquots of supernatant and the pellet were separately counted in a $\beta$-counter (Kontron Liquid Scintillation System MR 300, Kontron AG, Birsfelden, Switzerland).

We tested the inhibitory effect of the following substances on the uptake of fosfomycin and rifampicin: iodacetamide $(0.1$ and $5 \mathrm{mM}$, Fluka, Buchs, Switzerland), DOG (1 mM, Sigma, St. Louis, MO), KCN (10 mM, Merck, Darmstadt, FRG) and snglycero-3-phosphate ( $5 \mu \mathrm{M}$, Fluka). PMN were preincubated at $37^{\circ} \mathrm{C}$ for $10 \mathrm{~min}$ in HBSS with the inhibitors. The subsequent test procedure was the same as described above.

Total and extracellular water spaces in the PMN-sediment were measured with labeled water $\left({ }^{3} \mathrm{H}_{2} \mathrm{O}\right.$, specific activity: 0.25 $\mu \mathrm{Ci} / \mathrm{mg}, \mathrm{NEN}$ ) and inulin (carboxy $\left[{ }^{14} \mathrm{C}\right]$ inulin, $2.5 \mu \mathrm{Ci} / \mathrm{mg}$, NEN). The procedure differed from antibiotic uptake in that aliquots were taken 5 resp. 10 min after addition of ${ }^{3} \mathrm{H}_{2} \mathrm{O}$ and $\left[{ }^{14} \mathrm{C}\right]$ inulin and the centrifuge tubes did not contain sucrose, which would have interfered with $\mathrm{H}_{2} \mathrm{O}$ within the cells to be measured (14). Calculations were as follows (20): Total $\left(V_{t}\right)$, extracellular $\left(\mathrm{V}_{\mathrm{e}}\right)$, and intracellular $\left(\mathrm{V}_{\mathrm{i}}\right)$ water spaces of cell pellet:

$$
\begin{gathered}
\mathrm{V}_{\mathrm{t}}=\frac{\mathrm{dpm}{ }^{3} \mathrm{H}_{2} \mathrm{O} \text { (pellet) } \times \mu \mathrm{l} \text { (supernatant) }}{\mathrm{dpm}{ }^{3} \mathrm{H}_{2} \mathrm{O} \text { (supernatant) }} \\
\mathrm{V}_{\mathrm{e}}=\frac{\mathrm{dpm}\left[{ }^{14} \mathrm{C}\right] \text { inulin (pellet) } \times \mu \mathrm{l} \text { (supernatant) }}{\mathrm{dpm}\left[{ }^{14} \mathrm{C}\right] \text { Inulin (supernatant) }} \\
\mathrm{V}_{\mathrm{i}}=\mathrm{V}_{\mathrm{t}}-\mathrm{V}_{\mathrm{e}}
\end{gathered}
$$

Total $\left(\mathrm{AB}_{\mathrm{i}}\right)$, extracellular $\left(\mathrm{AB}_{\mathrm{e}}\right)$ and intracellular $\left(A \mathrm{~B}_{\mathrm{i}}\right)$ activity of radiolabeled antibiotics in cell pellet:

$$
\begin{gathered}
\mathrm{AB}_{\mathrm{t}}=\mathrm{dpm} \text { antibiotic (pellet) } \\
\mathrm{AB}=\frac{\mathrm{dpm} \text { antibiotic (supernatant) } \times \mathrm{V}_{\mathrm{e}}}{\mu \mathrm{l} \text { (supernatant) }} \\
\mathrm{AB}_{\mathrm{i}}=\mathrm{AB}_{\mathrm{t}}-\mathrm{AB}_{\mathrm{e}}
\end{gathered}
$$

Extracellular $(\mathrm{E})$ and intracellular $(\mathrm{C})$ concentration of antibiotics in cell pellet:

$$
\begin{aligned}
E & =\frac{A B_{e}}{V_{e}} \\
C & =\frac{A B_{i}}{V_{i}}
\end{aligned}
$$

$\mathrm{C} / \mathrm{E}=$ intracellular accumulation of antibiotics in PMN.

Killing of Staphylococcus aureus by PMN. Bacterial killing by PMN was tested according to a previously described method (21), but with certain modifications. $S$. aureus WOOD 46 showed minimal inhibitory concentrations (minimal bactericidal concentrations) of $0.03(2.0) \mathrm{mg} / \mathrm{liter}$ for fosfomycin, 0.0005 $(0.0008) \mathrm{mg} /$ liter for rifampicin, $0.002(0.008) \mathrm{mg} / \mathrm{liter}$ for penicillin $\mathrm{G}, 1.0(2.0) \mathrm{mg} /$ liter for trimethoprim, and $128(>256)$ $\mathrm{mg} /$ liter for sulfamethoxazole. In vitro studies of a combination of fosfomycin and rifampicin at various concentrations revealed no synergism or antagonism against extracellular bacteria.

For our experiments, bacteria were subcultured in tryptonewater broth overnight. The bacterial suspension was washed twice in $0.9 \% \mathrm{NaCl}$ and resuspended in HBSS + serum. After adjustment of optical density, the staphylococci $\left(5 \times 10^{8} \mathrm{CFU} / \mathrm{ml}\right)$ were opsonized in HBSS + serum for $10 \mathrm{~min}$ at $37^{\circ} \mathrm{C}$. Bacterial density was checked by plate colony counts.

After opsonization, $200 \mu \mathrm{l}$ of the bacterial suspension were added to a $20-\mathrm{ml}$ suspension of PMN in HBSS + serum $\left(1 \times 10^{7}\right.$ $\mathrm{PMN} / \mathrm{ml}$ ). Final count was adjusted to $5 \times 10^{6} \mathrm{CFU} / \mathrm{ml}$ in order to establish a bacteria/PMN ratio of 1:2. After incubation for 30 min at $37^{\circ} \mathrm{C}$ with constant rotation, the PMN suspension was carefully washed 3 times in cold $\mathrm{NaCl}(0.9 \%)$ in order to eliminate extracellular bacteria. Control experiments performed with Lysostaphin (10 mg/liter final concentration, Sigma) did not result in further reduction of extracellular bacteria.

PMN were resuspended in HBSS + serum and antibiotics were added at the following concentrations: fosfomycin (Boehringer) $=8,16,100,150,200 \mathrm{mg} /$ liter, rifampicin (Ciba Geigy) $=0.06$, $1.25 \mathrm{mg} /$ liter, fosfomycin (8 mg/liter) plus rifampicin $(0.06 \mathrm{mg}$ ) liter) simultaneously, penicillin $\mathrm{G}$ (Sigma) $=100 \mathrm{mg} /$ liter.

The antibiotic/PMN-suspension was incubated at $37^{\circ} \mathrm{C}$ and slowly rotated. At the beginning $(0 \mathrm{~min})$ and after 60,120 , and $180 \mathrm{~min}$ (occasionally at $240 \mathrm{~min}$ ), 1-ml aliquots of the suspension were taken, washed with HBSS, resuspended, and lysed in $\mathrm{H}_{2} \mathrm{O}$ for $15 \mathrm{~min}$ at $\mathrm{RT}$. Smears of the suspensions were performed and analyzed with a phase-contrast microscope to assure that all PMN were destroyed by this procedure. Then the samples were diluted 10-, 100-, 1000-, and 10,000-fold in HBSS and plated onto Müller-Hinton agar. CFUs were counted after incubation for $48 \mathrm{~h}$ at $37^{\circ} \mathrm{C}$.

Controls were as follows: PMN from healthy blood donors instead of CGD-PMN (with and without antibiotics), CGD-PMN and bacteria (without antibiotics), and extracellular bacteria alone (with and without antibiotics).

Influence of fosfomycin on normal PMN function. PMN from healthy blood donors were suspended in HBSS containing fosfomycin at different concentrations $(50,100,200,400,1000 \mathrm{mg}$ / liter) and compared to controls without fosfomycin. The following tests were performed in order to assess alterations of normal granulocyte functions by fosfomycin.

Phagocytosis assay. Phagocytosis of yeast cells by PMN was tested as described previously (22) with several modifications. In brief, yeast cells $\left(2.5 \times 10^{8} / \mathrm{ml}\right)$ were exposed to PMN $\left(5 \times 10^{6} /\right.$ $\mathrm{ml}$ ) in the presence of fresh human serum for $30 \mathrm{~min}$. After centrifugation, the pellet was thoroughly washed. The number of ingested yeast particles per $100 \mathrm{PMN}$ was counted after counterstain of extracellular yeast cells with Ziehl-Fuchsin stain.

Chemotaxis-assay. Chemotactic activity of PIN was evaluated according to the "migration-under-agarose" method reported by Nelson et al. (16). ZAS was used as a chemotactic factor. Results were expressed as the difference between activated (A) and spontaneous (B) migration of PMN, measured in $\mu \mathrm{m}$. 
Chemiluminescence assay. Chemiluminescence of stimulated PMN was tested as previously described (1). Emission of light impulses by PMN in the presence of luminol (Sigma) was registered with a photometer (Luminometer 1251, LKB Wallac, Turku, Finland) and recorded graphically. PMN were stimulated with PMA and OPZ, respectively. Control experiments were performed with fosfomycin at the same concentrations as mentioned above, but without PMN. Results were expressed in $\mathrm{mV} /$ $\min / 10^{6} \mathrm{PMN}$.

Oxygen consumption assay. Consumption of oxygen by stimulated PMN was tested with an oxygraph (no. 5/6, Gilson Medical Electronics, Middleton, WI) according to a method previously described (19). Again, PMN were stimulated with either PMA or OPZ. Results were expressed in $\mathrm{nmol} \mathrm{O}_{2} / \mathrm{min} / 5$ $\times 10^{6} \mathrm{PMN}$.

Statistical analysis. Statistical anaysis was performed using the Student's $t$ test.

\section{RESULTS}

Uptake of $\beta$ H]fosfomycin into normal PMN. Fosfomycin was slowly accumulated within the PMN and reached its maximal intracellular concentration after $15 \mathrm{~min}$ (Fig. $1 A$ ). The $\mathrm{C} / \mathrm{E}$ ratio was 1.83 at that time. After another $15 \mathrm{~min}$, the $\mathrm{C} / \mathrm{E}$ ratio was 1.63. In comparison, $\left[{ }^{14} \mathrm{C}\right]$ penicillin (Fig. $1 A$ ) was not accumulated within the PMN $(\mathrm{C} / \mathrm{E}<1)$. The influx of rifampicin was faster and reached significantly higher accumulation rates than that of fosfomycin $\left(C / E_{\max }=9.8\right.$ after $\left.20 \mathrm{~min}\right)$. The corresponding values for TMP and SMZ were situated between those for fosfomycin and rifampicin, both in respect to amount and kinetics of intracellular uptake $\left(\mathrm{C} / \mathrm{E}_{\max }=2.26\right.$ and 3.56, respectively, at $10 \mathrm{~min}$ ).

Uptake of $\left.{ }^{3} H\right]$ fosfomycin into CGD-PMN. CGD patients were equally capable to accumulate fosfomycin inside their PMN (Fig. $1 B$ ). The $\mathrm{C} / \mathrm{E}$ ratio increased slowly and continuously over a period of $30 \mathrm{~min}$ and the $\mathrm{C} / \mathrm{E}_{\max }$ of 2.18 was slightly higher than in normal PMN (1.83). However, a statisticallly significant difference between normal and CGD-PMN could only be observed at one point $(3 \mathrm{~min}, p<0.05)$. The rate of intracellular accumulation of TMP $\left(\mathrm{C} / \mathrm{E}_{\max }=3.15\right.$ after $\left.5 \mathrm{~min}\right)$ was again intermediate between that of rifampicin $\left(C / E_{\max }=12.84\right.$ after 10 min) and fosfomycin, while penicillin was not accumulated within CGD-PMN (C/E $\mathrm{E}_{\max }=0.65$ after $20 \mathrm{~min}$ ) (Fig. $\left.1 B\right)$.

Inhibition of $\beta$ H]fosfomycin uptake into normal PMN. Four metabolic inhibitors were examined for their ability to impede intracellular uptake of fosfomycin: sn-glycero-3-phosphate is transported mainly by the sn-glycero-3-phosphate-transport-system present in cell membranes. In bacteria, it was shown to competitively inhibit the transport of structural analogues such as fosfomycin (12) (Fig. 2). Iodacetamide inactivates sulfhydryl groups, e.g. of transport enzymes. $\mathrm{KCN}$ is a potent inhibitor of the intramitochondrial ATP generation. DOG competitively inhibits glycolysis and ATP-dependent transport processes $(11,14)$. Figure 2 demonstrates the effect of these agents on fosfomycin uptake into normal PMN. Intracellular accumulation was absent in all cases (with $\mathrm{C} / \mathrm{E} \leq 0.8, p<0.05$, resp $<0.01$ ) except iodacetamide, where inhibition was only seen at a concentration of $5.0 \mathrm{mM}$, with no effect at $0.1 \mathrm{mM}$. In contrast, the rapid uptake of rifampicin into PMN is not inhibited by any of these agents (data not shown, $c f$. Ref. 14).

Killing of intracellular staphylococci in CGD-PMN by fosfomycin. CGD-PMN are unable to kill phagocytized bacteria adequately (17). As shown in Figure $3 A$, the number of intracellularly surviving bacteria slowly increased during the $3 \mathrm{~h}$ incubation period, whereas normal PMN rapidly killed the phagocytized staphylococci. Fosfomycin significantly reduced the number of intracellular bacteria in CGD-PMN (Fig. 3, C-F). At concentrations between 16 and $200 \mathrm{mg} /$ liter, i.e. well within therapeutically achieved serum levels $(8,13)$, this effect was not dose dependent. Killing curves of CGD-PMN in the presence of fosfomycin resembled killing curves of normal PMN without antibiotics (Fig. $3 A$ ). This effect could be observed at different concentra-

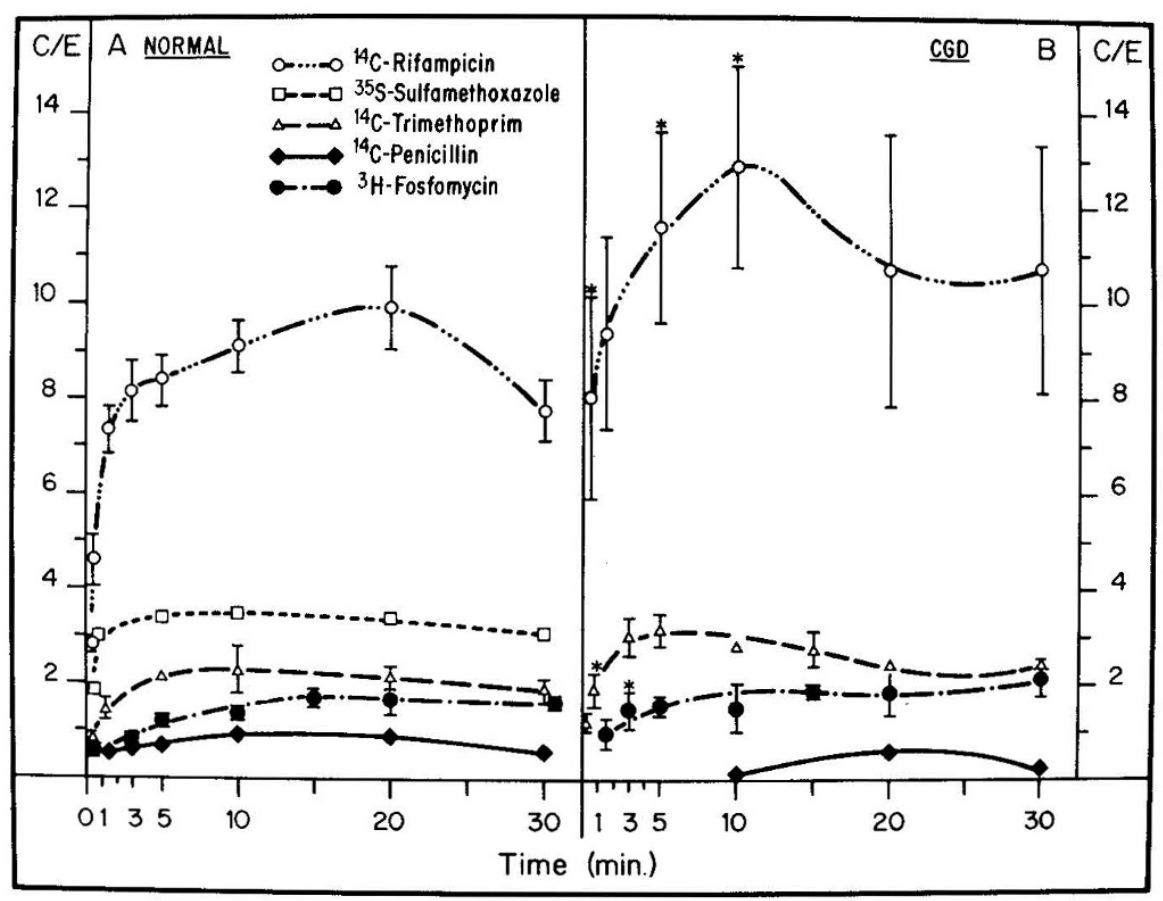

Fig. 1. A, means $\pm \mathrm{SEM}$ are given for rifampicin (3-12 single determinations in 12 healthy blood donors), trimethoprim (one to six determinations in six blood donors), and fosfomycin (five to 14 determinations in 14 blood donors). Mean values are given for sulfamethoxazole (one to two determinations in two blood donors) and penicillin (2 determinations in two blood donors). $B$, means \pm SEM are given for rifampicin (three to five determinations in five CGD patients), trimethoprim (one to six determinations in six CGD), and fosfomycin (four to nine determinations in nine CGD). Penicillin was tested in a single patient. *denotes statistically significant differences $(p<0.05)$ for antibiotic uptake into normal versus CGDPMN. 


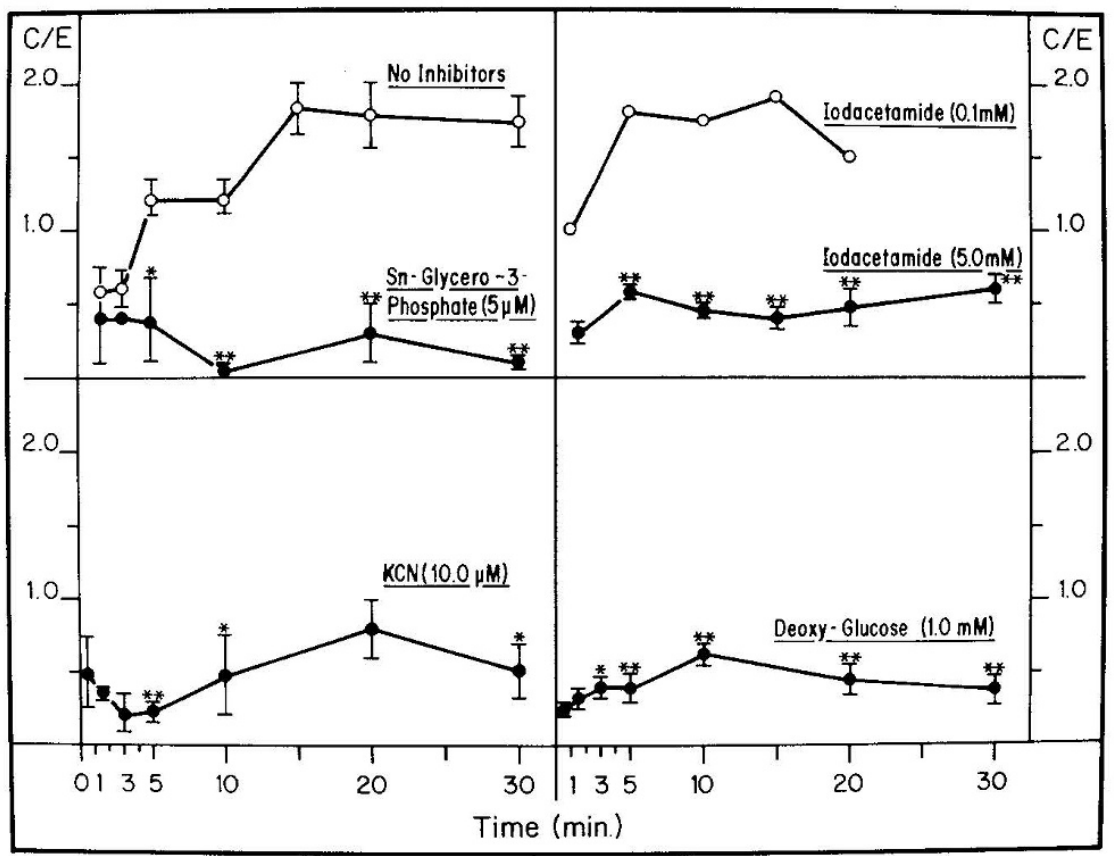

Fig. 2. Means \pm SEM of one to nine single determinations in one to nine different healthy blood donors. Statistical analysis was performed comparing uptake of $\left[{ }^{3} \mathrm{H}\right]$ fosfomycin in the presence and absence of metabolic inhibitors $\left({ }^{*} p<0.05,{ }^{* *} p<0.01\right)$.

tions of fosfomycin. In PMN from healthy donors no further enhancement of bactericidal activity by fosfomycin could be observed (data not shown).

The same intracellular bactericidal activity was seen with rifampicin, whereas penicillin exhibited little and only retarded effect against the intracellular organisms (Fig. $3 B$ ). After $3 \mathrm{~h}$, about $60 \%$ of the ingested staphylococci were still alive despite bactericidal concentrations of penicillin in the extracellular medium, as compared with $1-7.5 \%$ in case of fosfomycin or rifampicin (Fig. $3 B-F$ ).

Both fosfomycin and rifampicin were still active against the intracellular staphylococci at low concentrations ( 8 and $0.06 \mu \mathrm{g} /$ $\mathrm{ml}$, respectively) (Fig. $3 G$ ), although to a somewhat smaller degree. If both antibiotics were combined at these concentrations, the extent of killing was significantly better than with fosfomycin alone, with a survival rate as low as $3.5 \%$ after $3 \mathrm{~h}$ (Fig. $3 H$ ).

Influence of fosfomycin on normal PMN function. Results of functional assays are summarized in Table 1 . Between 50 and $1000 \mathrm{mg}$ fosfomycin/liter (the latter concentration exceeding normal therapeutic plasma levels by far) $(8,13)$, no consistent effect of fosfomycin on phagocytosis, chemotaxis, and oxygen consumption could be seen.

Chemiluminescence activity, however, was significantly stimulated in the presence of fosfomycin, reaching 201 resp $218 \%$ of normal (stimulus OPZ resp PMA) at $400 \mathrm{mg}$ fosfomycin/liter. No such effect was observed in the absence of PMN at any concentration of fosfomycin.

\section{DISCUSSION}

The capacity of certain antibiotics to penetrate cell membranes represents an important prerequisite for their efficacy in vivo (10, $11,15,29)$. After phagocytosis, bacteria may survive within the PMN (and other cells) and remain unaffected by antimicrobial agents unable to reach the intracellular space. This holds particularly true for $\beta$-lactam antibiotics and aminoglycosides (29). Only if extracellular concentrations of these latter antibiotics are significantly increased, they are able to combat intracellular infections effectively (27).

On the other hand, there are a number of antibiotics with known intracellular accumulation and efficacy against intracellular pathogens, whose clinical applicability might be limited by their adverse effects on important neutrophil functions. Tetracyclines, for instance, which are accumulated within the cells about 7 -fold $(6,29)$, inhibit chemotaxis as well as phagocytosis and oxidative metabolism of PMN (29). Such inhibitory actions of antibiotics on host defense mechanisms might be critical in immunocompromised hosts.

Thus, in patients with impaired neutrophil functions, only a few antibiotics can be recommended. In CGD, defective bactericidal activity calls for continuous prophylaxis with an intracellularly active antibiotic $(20,21,26)$. Since TMP/SMZ has been introduced into the management of CGD patients, the prognostic outcome of this disease has favorably improved (26). TMP/SMZ has been shown to accumulate within PMN $(6,21)$ without affecting other cellular functions (2). Rifampicin also proved to be effective in $\operatorname{CGD}(4,20)$.

While these two antibiotics are able to permeate cell membranes due to their high lipid solubility $(6,11,15,20)$, fosfomycin is known to be hydrophilic and, therefore, passive transmembraneous diffusion is an unlikely explanation for its uptake. Kahan et al. (12) demonstrated the existence of two different active transport mechanisms for fosfomycin. The agent is accumulated by many (but not by all) bacteria via the sn-glycero-3-phosphate transport system. Under certain conditions, the glucose-6-phosphate system, which can be induced externally, may also be used for the transport of the substance.

In the present study we could show that fosfomycin is taken up by human PMN (Fig. 1) and that its accumulation is hindered by sn-glycero-3-phosphate as well as by agents interfering with energy-requiring processes (Fig. 2). This strongly suggests the presence of a similar active transport mechanism for fosfomycin in human PMN as described for this drug in bacteria.

The relative amount of fosfomycin accumulated in PMN is significantly smaller than that of rifampicin $\left(C / E_{\max }=1.83\right.$ versus 9.8, in normal $\mathrm{PMN}$ ). However, the degree of $\mathrm{C} / \mathrm{E}$ ratios might be only of minor importance as long as the critical value of 1.0 is exceeded, where accumulation starts. Intracellular bacteria will be killed as soon as the antibiotic reaches a bactericidal concentration within the PMN.

In CGD-PMN, fosfomycin even exceeds the C/E ratio of 2. This phenomenon of increased uptake into CGD-PMN has also been observed with TMP/SMZ and rifampicin (14, 21) (Fig. 3). In the latter two instances, it might be attributed to a somewhat 


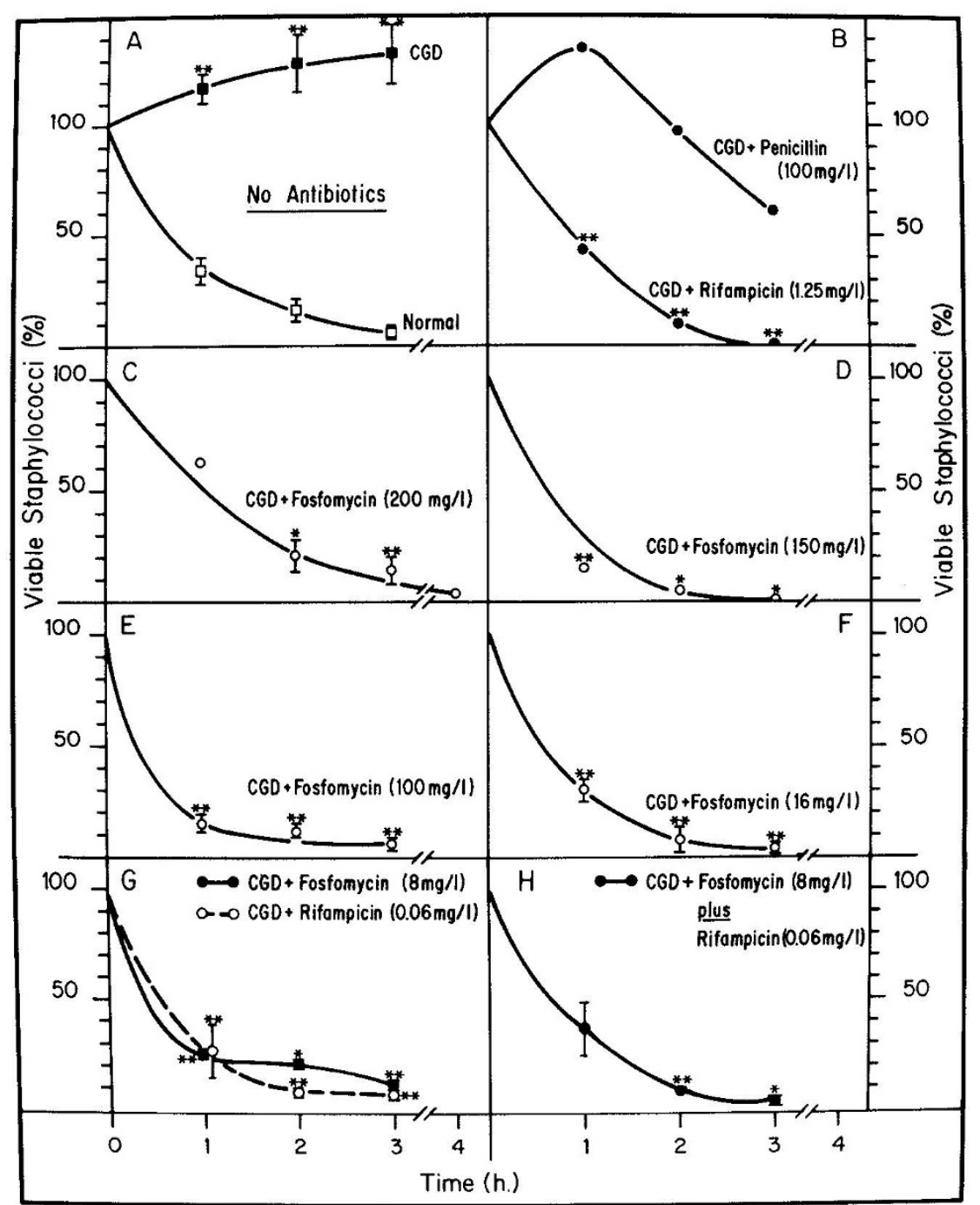

Fig. 3. A, CGD: means \pm SEM of 12 to 18 single determinations in eight different CGD patients. Normal: means \pm SEM of 19 single determinations in 19 healthy blood donors. B, penicillin and rifampicin effects: means of two single determinations in 2 CGD patients. $C-F$, fosfomycin dose response: means \pm SEM of one to three single determinations in 5 CGD-patients. $G$, fosfomycin and rifampicin effects: means \pm SEM of two responses, three single determinations in three CGD-patients. $H$, means \pm SEM of five single determinations in 4 CGD patients. Statistical significance: $\left({ }^{*} p<0.05,{ }^{* *} p<0.01\right)$ was tested in $(A)$ CGD versus normal PMN. B, rifampicin versus no antibiotics in CGD. There was no statistically significant difference in bacterial killing between CGD-PMN with or without penicillin. $C-F$, fosfomycin versus no antibiotics. $G$, fosfomycin resp rifampicin versus no antibiotics. In $B-G$, the difference between rifampicin resp fosfomycin versus penicillin was also statistically significant $(p<0.05-0.01)$. There was no statistically significant difference in killing efficacy between various concentrations of fosfomycin or between fosfomycin and rifampicin. $H$, combination of fosfomycin plus rifampicin versus fosfomycin alone.

Table 1. Influence of different concentrations of fosfomycin on normal human granulocyte function

\begin{tabular}{|c|c|c|c|c|c|c|c|}
\hline \multirow[b]{3}{*}{$\begin{array}{l}\text { Fosfomycin } \\
\text { concentration } \\
(\mathrm{mg} / \mathrm{liter})\end{array}$} & \multirow{2}{*}{ Phagocytosis } & \multirow{2}{*}{\multicolumn{2}{|c|}{$\frac{\text { Chemotaxis }}{(\mu \mathrm{m} \text { of migration) }}$}} & \multirow{2}{*}{\multicolumn{2}{|c|}{$\begin{array}{c}\text { Oxygen-consumption } \\
\left(\mathrm{nmol} \mathrm{O} / \mathrm{h} / 5 \times 10^{6} \mathrm{PMN}\right)\end{array}$}} & \multirow{2}{*}{\multicolumn{2}{|c|}{$\begin{array}{c}\text { Chemiluminescence } \\
\left(\mathrm{mV} / \mathrm{min} / 5 \times 10^{6} \mathrm{PMN}\right)\end{array}$}} \\
\hline & & & & & & & \\
\hline & $\begin{array}{l}\text { (Phagocytized Yeast } \\
\text { Particles per } 100 \\
\text { PMN) }\end{array}$ & Activated (A) & Spontaneous (B) & $\begin{array}{l}\text { Stimulus } \\
\text { OPZ }\end{array}$ & $\begin{array}{l}\text { Stimulus } \\
\text { PMA }\end{array}$ & $\begin{array}{c}\text { Stimulus } \\
\text { OPZ }\end{array}$ & $\begin{array}{l}\text { Stimulus } \\
\text { PMA }\end{array}$ \\
\hline 0 & $990 \pm 33.1$ & $4.28 \pm 0.47$ & $1.79 \pm 0.29$ & $1522 \pm 122$ & $1458 \pm 124.5$ & $5967 \pm 646$ & $1564 \pm 232.3$ \\
\hline 50 & $937 \pm 31.9$ & $3.38 \pm 0.38$ & $1.48 \pm 0.38$ & $1629 \pm 139.7$ & $1214 \pm 118.4$ & $9264^{*} \pm 1453$ & $2573^{*} \pm 437.1$ \\
\hline 100 & $972 \pm 39.9$ & $3.47 \pm 0.39$ & $1.53 \pm 0.30$ & $1368 \pm 197.7$ & $1454 \pm 207.9$ & $10514^{* *} \pm 1409$ & $2439^{*} \pm 569$ \\
\hline 200 & $990 \pm 24$ & $3.87 \pm 0.44$ & $1.56 \pm 0.19$ & $1422 \pm 126.6$ & $1357 \pm 118$ & $10128^{* *} \pm 1092$ & $2646^{* *} \pm 481.6$ \\
\hline 400 & $945 \pm 29.2$ & $4.02 \pm 0.36$ & $1.36 \pm 0.23$ & $1383 \pm 161.6$ & $1389 \pm 113.3$ & $11997^{* *} \pm 1356$ & $3408^{* *} \pm 583$ \\
\hline 1000 & $959 \pm 18.6$ & $3.79 \pm 0.54$ & $1.40 \pm 0.19$ & $1584 \pm 169.2$ & $1827^{*} \pm 90.3$ & $10467^{* *} \pm 1105$ & $2811^{* *} \pm 296.4$ \\
\hline
\end{tabular}

Results are expressed as mean values \pm SEM. Statistical significance is indicated either with $*(p<0.05)$ or $* *(p<0.01)$. Number of tests performed per concentration: phagocytosis $=6$, chemotaxis $=14-24$, oxygen-consumption $=8-13$, chemiluminescence $=12-19$. 
lower $\mathrm{pH}$ value found inside CGD-PMN. After intracellular accumulation due to its lipid solubility (20), the weak base TMP is protonated within the PMN. This phenomenon is called "iontrapping" and prevents rediffusion. The model of partition along a $\mathrm{pH}$ gradient cannot be applied to fosfomycin, because its high polarity precludes passive diffusion. It is conceivable, however, that membrane transport activity (including the sn-glycero-3phosphate transport) might be increased in CGD, a disease involving the outer cell membrane of PMN (21).

An antibiotic taken up intracellularly can only be useful clinically if it retains its bactericidal activity. Our data proved for the first time that fosfomycin is indeed able to compensate entirely for the lack of bactericidal capacity in CGD-PMN (Fig. $3)$. Regardless of their higher $\mathrm{C} / \mathrm{E}$ ratios, rifampicin and TMP/ SMZ do not lead to any further improvement in intracellular killing (Fig. 3B: rifampicin) (21).

Administration of 25 resp $50 \mathrm{mg}$ fosfomycin per $\mathrm{kg}$ body weight iv in infants suffering from gram-negative infections resulted in peak plasma levels (at $15 \mathrm{~min}$ ) of 102 and $194 \mathrm{mg} /$ liter, respectively (7). At $2 \mathrm{~h}$ after dose (i.e. one serum half-life of the drug) (13), the corresponding values were 22 and $50 \mathrm{mg} /$ liter, respectively. Within this range of concentrations, no dose dependence was found for the intracellular bactericidal activity of fosfomycin within CGD-PMN (Fig. $3 C-F$ ).

The intracellular activity of fosfomycin has previously been described using normal PMN. Takashima et al. (23) reported 99\% reduction of CFU (salmonella within leukocytes) in the presence of $25-100 \mathrm{mg} /$ liter fosfomycin. Traub (24) demonstrated the intraphagocytic efficacy of this antibiotic (using phenylbutazone-treated leukocytes not separated from whole blood). At $32 \mathrm{mg} /$ liter, fosfomycin reduced about $89 \%$ of CFU (Serratia marcescens) and was comparable in its efficacy to rifampicin, whereas cephalosporines were ineffective.

Unlike many other broad spectrum antibiotics, fosfomycin did not impede neutrophil functions (Table 1). On the contrary, we observed a stimulation of chemiluminescence by this agent. At high concentrations oxygen consumption was also increased. It would nevertheless be premature to hypothesize a stimulatory effect of fosfomycin on PMN activity, especially since diminution of chemiluminescence caused for instance by TMP (27) did not result in inhibition of neutrophil function. Further investigations are underway to analyze this phenomenon and its significance in CGD-PMN.

Fosfomycin has both the bacteriological and pharmacological characteristics necessary for an antibiotic effective in CGD. It reveals broad antibacterial activity against bacteria isolated in this disease (21): gram-positive such as staphylococci, and gramnegative such as Escherichia coli, enterobacter, citrobacter, Proteus mirabilis, vulgaris, and rettgeri, $S$. marcescens, salmonella, and in part klebsiella and pseudomonas $(5,8,28)$. Due to its small molecular weight, diffusion into all organic fluids and tissues is easily achieved, including meninges, lung tissue, and bones $(9,13,28)$. Its applicability and efficacy in osteomyelitis and respiratory tract infections are well documented. Chronic pulmonary infections and osteomyelitis are frequent problems in CGD patients (29) and in other immunocompromised patients.

However, it must be born in mind that fosfomycin rapidly induces resistance if given as monotherapy over a longer period $(7,18,28)$. A combination with rifampicin could diminish this risk and therefore be of value in the treatment of severe infections, especially in CGD patients, where short-term treatment rarely is effective. Previous in vitro studies have demonstrated synergism between fosfomycin and rifampicin as well as between fosfomycin and other antibiotics $(9,18)$. At the extracellular level, we could not confirm these observations. At the intracellular level, however, a combination of fosfomycin plus rifampicin (Fig. $3 H$ ) was more active than each antibiotic alone. This intracellular synergism between fosfomycin and rifampicin is yet to be confirmed by additional experiments.
Clinical studies are indicated to investigate the efficacy of fosfomycin alone and in combination with rifampicin for therapy of chronic intracellular infections and especially for serious infections in CGD patients.

Acknowledgments. We are indebted to the following colleagues who referred patients with diagnosed or suspected CGD for study: PD Dr. B. Belohradsky, Univ.-Kinderklinik München, Dr. A. Campelli, Istituto G. Gaslini, Genova, Dr. W. Ebell, Univ.Kinderklinik Düsseldorf, Dr. W. Wahlen, Univ.-Kinderklinik Homburg (Saar), Dr. V. Wahn, Univ.-Kinderklinik Düsseldorf. Prof. F. Kayser, Institute of Medical Microbiology, University of Zürich, kindly performed the determinations of minimal inhibitory and minimal bactericidal concentrations of the Staphylococcus aureus used in the above experiments. Dr. R. Haag, Boehringer Mannheim AG, Mannheim, performed the tests for extracellular synergism between fosfomycin and rifampicin. We thank Dr. K. Vosbeck, Ciba Geigy AG, Basle, for teaching us the intracellular bacterial killing method. We are grateful for the skillful technical assistance of Ingrid Weissbrodt. $S$. aureus WOOD 46 was supplied by Dr. K. Vosbeck.

\section{REFERENCES}

1. Allen RC, Stjernholm RL, Steele RH 1972 Evidence for the generation of an electronic excitation state(s) in human polymorphonuclear leukocytes and its participation in bactericidal activity. Biochem Biophys Res Commun 47:679-684

2. Anderson R, Grabow G, Oosthuizen R, Theron A, Van Rensburg AJ 1980 Effects of sulfamethoxazole and trimethoprim on human neutrophils and lymphocyte functions in vitro: in vivo effects of co-trimoxazole. Antimicrob Agents Chemother 17:322-326

3. Böyum A 1976 Isolation of lymphocytes, granulocytes and macrophages. Scand J Immunol 5(suppl 5):9-15

4. Ezer G, Soothill JF 1974 Intracellular bactericidal effects of Rifampicin in both normal and chronic granulomatous disease polymorphs. Arch Dis Child 49:463-466

5. Forsgren A, Walder M 1983 Antimicrobial activity of Fosfomycin in vitro. J Antimicrob Chemother 11:467-471

6. Gmünder FK, Seger RA 1981 Chronic granulomatous disease: mode of action of sulfamethoxazole/trimethoprim. Pediatr Res 15:1533-1537

7. Grassi GG, Ferrara A, Sala P 1980 Mechanism of the synergistic activity of different combinations of trimethoprim, ampicillin, fosfomycin and rifampicin. Drugs Exp Clin Res 6:269-276

8. Guggenbichler JP, Kienel G, Frisch H 1978 Fosfomycin, ein neues Antibiotikum. Pharmakokinetische Untersuchungen bei Kindern, Früh- und Neugeborenen. Pädiatr Pädolog 13:429-436

9. Guggenbichler JP, Kienel G, Frisch J 1979 Fosfomycin in clinical pediatrics. Drugs Exp Clin Res 5:367-371

10. Jacobs RF, Wilson CB 1983 Activity of antibiotics in chronic granulomatous disease of childhood. Pediatr Res 17:916-919

11. Johnson JD, Hand WL, Francis JB, King-Thompson N, Corwin RW 1980 Antibiotic uptake by alveolar macrophages. J Lab Clin Med 95:429-439

12. Kahan FM, Kahan JS, Cassidy PJ, Kropp H 1974 The mechanism of action of fosfomycin (phosphonomycin). Ann NY Acad Sci 235:364-386

13. Kirby WMM 1977 Pharmacokinetics of fosfomycin. Chemotherapy 23(suppl 1): $141-151$

14. Knecht K 1983 Rifampicin und Menschliche Granulocyten, Thesis paper, Faculty of Medicine, University of Zürich

15. Mandell GL 1973 Interaction of intraleukocytic bacteria and antibiotics. J Clin Invest 52:1673-1679

16. Nelson RD, Baumann MP, Gracyk JL, Fiegel VD, Herron MJ 1981 Leukocyte chemotaxis: migration under agarose method. In: Douglas SD, Quie PG (eds) Investigations of Phagocytes in Disease. Churchill Livingstone, Edinburgh, pp $21-31$

17. Quie PG, White JG, Holmes B, Good RA 1967 In vitro bactericidal capacity of human polymorphonuclear leukocytes: diminished activity in chronic granulomatous disease of childhood. J Clin Invest 46:668-679

18. Rodriquez A, Olay T, De Vicente MV 1980 Synergic activity of fosfomycin in association with other antibacterial agents: a review. Drugs Exp Clin Res 6:281-288

19. Segal AW, Coade SB 1978 Kinetics of oxygen consumption by phagocytizing human neutrophils. Biochem Biophys Res Commun 84:611-617

20. Seger R 1984 Inborn errors of oxygen-dependent microbial killing by neutrophils. Ergeb Inn Med Kinderheilkd 51:31-116

21. Seger RA, Baumgartner S, Tiefenauer LX, Gmünder FK 1981 Chronic granulomatous disease: effect of sulfamethoxazole/trimethoprim on neutrophil microbicidal function. Helv Paediatr Acta 36:579-588

22. Simpson DW, Roth R, Loose LD 1979 A rapid, inexpensive and easily quantified assay for phagocytosis and microbicidal activity of macrophages and neutrophils. J Immunol Meth 29:221-226

23. Takashima T, Hiromatsu K, Tabuki T, Nishimura T 1981 Clinical and 
bacteriological effect of fosfomycin (FOM) on salmonella infections-effect of FOM on the phagocytic action of human leukocytes against salmonella, 12. International Congress of Chemotherapy, Florence, Italy, 1981, abstr 661

24. Traub WH 1983 Interactions of antimicrobial drugs and combined phagocytic/ serum bactericidal activity of defibrinated human blood against serratia marcescens. III. Beta-lactam-antibiotics and fosfomycin. Chemotherapy 29:48-57

25. Veale DR, Finch H, Smith H 1976 Penetration of penicillin into human phagocytes containing Neisseria gonorrhoeae: intracellular survival and growth at optimum concentrations of antibiotic. J Gen Microbiol 95: 353363
26. Weening RS, Kabel P, Pijman P, Roos D 1983 Continuous therapy with sulfamethoxazole-trimethoprim in patients with chronic granulomatous disease. J Pediatr 103:127-130

27. Welch WD, Davis D, Thrupp LD 1981 Effect of antimicrobial agents on human polymorphonuclear leukocyte microbicidal function. Antimicrob Agents Chemother 20:15-20

28. Woodruff HB, Mata JM, Hernández S, Mochales S, Rodriguez A, Stapley EO, Wallick H, Miller AK, Hendlin D 1977 Fosfomycin: laboratory studies. Chemotherapy 23(suppI 1):1-22

29. Yourtee EL, Root RK 1982 Antibiotic-neutrophil interactions in microbicida killing. In: Gallin JL, Fauci AS (eds) Advances in Host Defense Mechanisms, Vol I. Raven Press, New York, pp 187-209

\title{
Age-Related Red Cell Enzymes in Children with Transient Erythroblastopenia of Childhood and with Hemolytic Anemia
}

\author{
ERNEST BEUTLER AND GARY HARTMAN \\ Scripps Clinic and Research Foundation, Department of Basic and Clinical Research, La Jolla; and Children's \\ Hospital of San Diego, San Diego, California
}

\begin{abstract}
Red cell enzymes of three children with transient erythroblastopenia of childhood were measured and compared with those of age-matched normal children and children with hemolytic anemia. While the activity of "age-dependent" enzyme such as hexokinase, aldolase, glucose-6-phosphate dehydrogenase, glutamic-oxaloacetic transaminase, and pyruvate kinase were greatly increased in the red cells of children with hemolytic anemia, they were not decreased in the red cells of children with erythroblastopenia of childhood. Only the activity of pyrimidine $5^{\prime}$-nucleotidase was consistently low red cells of these chidren. These findings are inconsistent with the usual concept that red cell enzyme activities decline throughout red cell life span. Rather, they suggest that there may be very rapid loss in the activity of some red cell enzymes during the first few days of red cell life with little further decline in enzyme activity. (Pediatr Res 19: 44-47, 1985)
\end{abstract}

Transient erythroblastopenia of childhood is a relatively uncommon disorder of infants and young children. It is characterized by a profound but transient cessation of erythropoiesis followed within a few weeks or months by complete recovery (1).

We have recently had the opportunity to study red cell enzymes in three children with this relatively rare disorder and to compare

Received December 1, 1983; accepted July 23, 1984.

Correspondence Dr. Ernest Beutler, Scripps Clinic and Research Foundation, Department of Basic and Clinical Research, 10666 North Torrey Pines Road, La Jolla, CA 92037.

This work was funded in part by NIH Division of Heart, Lung and Blood Grant HL25552.

Publication 3136BCR from the Research Institute of Scripps Clinic and Research Foundation. the levels of red cell enzymes with those of children in the same age group who have hemolytic anemia. These investigations have provided us with some interesting new insights into the manner in which red cell enzyme activities, particularly that of pyrimidine-5'-nucleotidase, decline with increasing red cell age.

\section{PATIENTS}

M.R., born on January 7, 1982, of Mexican-American parents was first seen at 15 months of age. He had a history of an upper respiratory infection 2 months prior to being seen. This had been treated with aspirin and with antibiotics. His $\mathrm{Hb}$ was $5.6 \mathrm{~g} / 100$ $\mathrm{ml}$, hematocrit was $16.3 \%$, red count was 1.9 million $/ \mu \mathrm{l}$, white count was $6400 / \mu \mathrm{l}$ with a normal differential, and reticulocyte count was $0.2 \%$. Bone marrow aspiration revealed normal cellularity with only $8 \%$ total erythroid cells. A blood sample was drawn for enzyme assay. The pyrimidine $5^{\prime}$-nucleotidase activity was 36.7 units/g $\mathrm{Hb}$ (mean normal $\pm 1 \mathrm{SD}=138.8 \pm 18.91$ $\mathrm{mU} / \mathrm{g} \mathrm{Hb}$ ). The patient was given a single transfusion of $160 \mathrm{ml}$ of packed red cells. His reticulocyte count gradually rose and reached $1.3 \% 10$ wk after first being seen. At this time his $\mathrm{Hb}$ was $14.8 \mathrm{~g} / 100 \mathrm{ml}$, hematocrit of $43.8 \%$, and red count of 4.96 million.

C.H. was born on September 2, 1981. He was first seen at 19 months of age with a history of recurrent upper respiratory infection and diarrhea for the preceding 4-5 wk. His hematocrit had been found to be $23 \% 1$ wk earlier, and he had been placed on iron. His past history was significant only in that he had received exchange transfusions only because of $\mathrm{Rh}$ incompatibility.

The $\mathrm{Hb}$ was $7.4 \mathrm{~g} / 100 \mathrm{ml}$, hematocrit was $21.4 \%$, the white count was $10,300 \mu \mathrm{l}$, platelets were $344,000 \mu \mathrm{l}$, and the differential was normal. The reticulocyte count was recorded as $0 \%$. Bone marrow examination showed only $5 \%$ total erythroid cells. After blood was drawn for red cell enzyme assays. the patient 